\title{
PELATIHAN PEMBELAJARAN ONLINE PADA MASA PANDEMI COVID-19 BAGI GURU-GURU ANGGOTA KN-LWF PEMATANGSIANTAR
}

\author{
Ridwin Purba ${ }^{1}$, Asnewastri $^{2}$, Ahmad Fakhri Hutauruk ${ }^{3}$, Andres M.Ginting ${ }^{4}$, Resmi $^{5}$ \\ ${ }^{1}$ Prodi Pendidikan Bahasa Inggris, Universitas Simalungun \\ 2,3,4 Prodi Pendidikan Sejarah, Universitas Simalungun \\ ${ }^{5}$ Prodi Pendidikan Bahasa dan Sastra Indonesia, Universitas Simalungun \\ email: nridwin@yahoo.com
}

\begin{abstract}
Abstrak
Kegiatan pengabdian kepada masyarakat yang dilakukan oleh tim dari PKM Universitas Simalungun pada tanggal 31 Maret 2021 bertempat di SMK GKPI 1 Pematangsiantar ini telah memberikan sumbangan yang sangat berarti bagi 40 guru-guru sekolah swasta di Pematangsiantar. Pelatihan tentang Pembelajaran Online pada masa Pandemi Covid 19 merupakan salah satu cara untuk membantu guru-guru untuk melakukan Pembelajaran di Era Revolusi Industri 4.0, Strategi Pembelajaran Online, Media pembelajaran Online, Aplikasi Pembelajaran Online, dan Pembelajaran di Era Pandemi. Kegiatan pengabdian masyarakat ini dapat dijadikan sebagai langkah awal untuk membantu guru-guru yang kesulitan dalam melaksanakan proses pembelajaran online karena situasi pandemi yang sedang berlangsung. Pelatihan menunjukkan bahwa guru-guru memiliki keinginan besar untuk mendapatkan informasi dan pengetahuan mengenai Pembelajaran di Era Revolusi Industri 4.0, Penggunaan Strategi, Media, dan Aplikasi yang dapat digunakan dalam menunjang proses pembelajaran yang efektif.
\end{abstract}

Kata Kunci: Pelatihan, Pembelajaran Online, Pandemi Covid19

\begin{abstract}
The community service activity which was carried out by the team Simalungun University Community Service on the $31^{\text {st }}$ March 2021 in SMK GKPI 1 Pematangsiantar has given meaningful contribution to the 40 private teachers in Pematangsiantar. Training on Online Teaching at the time of Covid-19 Pandemic is one of the ways to help the teachers to do the Teaching in the era of Industry Revolution 4.0, Online Teaching Strategy, Online Teaching Media, Online Teaching Application and Teaching during Covid-19 Pandemic. The community service activity can be used as the starting point to help the teachers who face difficulties to do online teaching because of the pandemic. The training shows that the teachers have strong wish to get information and knowledge about the Teaching in the era of Industry Revolution 4.0, the Usage of Strategy, Media and Application which can be used to support the process of effective teaching.
\end{abstract}

Keywords: Training, Online Learning, Covid-19 Pandemic

\section{PENDAHULUAN}

Lebih dari $91 \%$ populasi siswa dunia telah dipengaruhi oleh penutupan sekolah karena pandemi COVID-19 (UNESCO), Bagaimana sistem pendidikan nasional dapat memastikan bahwa semua siswa memiliki akses yang sama untuk pendidikan berkualitas selama krisis yang belum pernah terjadi sebelum ini. Perkembangan teknologi telah dirasakan oleh hampir semua lapisan masyarakat Indonesia meliputi bidang informasi, komunikasi dan sebagainya. Guru-guru sekolah Swasta di Pematangsiantar mendapat dampak dari pandemi Covid 19 terkait proses belajar mengajar, pembelajaran harus beradaptasi dengan sistem online untuk mendukung program pemerintah yang melarang adanya tatap muka untuk mencegah cluster covid mewabah. Sebagai salah satu institusi pendidikan khususnya Fakultas Keguruan dan Ilmu Pendidikan Universitas Simalungun merasa memiliki tanggung jawab untuk memberikan penerangan dan informasi mengenai pembelajaran Online pada era Pandemi Covid 19. Untuk mencapai maksud di atas, dosen FKIP USI mengadakan program penyuluhan dan pelatihan kepada guru-guru sekolah di bawah naungan KN-LWF 
Pematangsiantar mengenai pentingnya pemanfaatan pembelajaran online yang baik pada situasi Pandemi sekarang ini.

Proses pembelajaran online di Indonesia dinilai kurang berhasil karena minimnya pembinaan baik formal ataupun non formal, bimbingan, pelayanan informasi, serta monitoring terhadap pelaksanaan setiap kebijakan kementerian pendidikan terkait implementasi teknologi di kalangan tenaga pengajar. Hal ini menimbulkan beberapa pemikiran permasalahan antara lain: 1) Bagaimana pemahaman guru-guru mengenai Pembelajaran 4.0?,2) Bagaimana pengguanan Strategi, Media, Aplikasi pembelajaran Online yang efektif?, 3) Penyampaian informasi pembelajaran di era Pandemi yang bagaimana akan digunakan agar guru-guru dapat dengan mudah dilaksanakan?

Bentuk penerangan dan penyuluhan yang bagaimana akan diberikan/disampaikan kepada guruguru sehingga diharapkan mereka dapat mengerti tentang pentingnya Pembelajaran Online dalam memanfaatkan teknologi tersebut secara baik dan aman. Tujuan Pembelajaran Online pada masa Pandemi adalah mencegah kesalahan penggunaan pembelajaran online yang keliru. Cara efektif untuk mencegah hal tersebut adalah pengambilan tindakan yang tepat terhadap guru-guru, agar mereka memiliki konsep pembelajaran Online yang efektif dan efesien sehingga diharapkan mampu memberikan wawasan tentang pentingnya pemilihan media, strategi, dan aplikasi pendukung pembelajaran online. Program pengabdian yang dirancang dengan kreatif dan inovatif diharapkan mampu mengantarkan tujuan USI yaitu pengembangan manusia yang beriman, bertaqwa, bermoral, berakhlak mulia, berilmu, profesional, religius, dan memiliki integritas dan cinta terhadap bangsa dan negara kesatuan Republik Indonesia.

Sosialisasi Pembelajaran Online pada era pandemi Covid 19 di wilayah binaan LPM USI yaitu di Pematangsiantar, sangat erat kaitannya dengan program pemerintah dalam rangka mencegah kerumunan massal karena proses pembelajaran tatap muka namun tetap dapat menyelesaikan kurikulum pemerintah tanpa meniadakan proses pembelajaran. Tujuan dari sosialisasi ini adalah agar guru-guru paham bagaiman pembelajaran 4.0, Penggunaan Strategi, Media, dan Aplikasi yang tepat, serta proses pembelajaran online yang efisien. Program ini pada akhirnya diharapkan dapat mensukseskan program pemerintah dan memberi dukungan bagi guru-guru melakukan proses belajar. Tujuan Belajar dari Rumah Melalui Pembelajaran Jarak Jauh 1. Memberikan pengalaman belajar yang bermakna bagi siswa, tanpa terbebani tuntutan menuntaskan seluruh capaian kurikulum kenaikan kelas maupun kelulusan. 2. Memfokuskan pada pendidikan kecakapan hidup antara lain mengenai pandemi Covid-19. 3. Memberikan variasi aktivitas dan tugas pembelajaran belajar dari rumah antarsiswa, sesuai minat dan kondisi masing-masing, termasuk mempertimbangkan kesenjangan akses/fasilitas belajar dari rumah. 4. Memberikan umpan balik terhadap bukti atau produk aktivitas belajar dari rumah yang bersifat kualitatif dan berguna bagi guru, tanpa diharuskan memberi skor/nilai kualitatif mengajar selama era pandemi.

\section{METODE}

Dalam program sosialisasi ini, digunakan beberapa metode, antara lain :

1. Metode ceramah, yaitu digunakan untuk memaparkan materi yang telah disusun oleh Tim Pelaksana.

2. Metode Tanya Jawab, yaitu digunakan untuk merespon sejauh mana tingkat pemahaman peserta sosialisasi terhadap yang telah disampaikan oleh Tim Pelaksana Pengabdian Kepada Masyarakat Universitas Simalungun

3. Metode diskusi, yaitu pemateri dan peserta melakukan dialog yang membahas masalah seputar Pembelajaran Online masa Pandemi Covid 19.

4. Metode Simulasi dan Praktek, yaitu digunakan untuk memperlihatkan penggunaan Strategi, Media, Serta Aplikasi yang tepat guna.

Berikut adalah pokok pikiran dari materi program sosialisasi:

1. Pedoman Penyelenggaraan Belajar dari Rumah dalam Masa Darurat Penyebaran Corona Virus Disease (Covid-19).

- Belajar dari Rumah selama darurat penyebaran Corona Virus Disease (COVID-19) dilaksanakan dengan tetap memperhatikan protokol penanganan COVID-19; dan

- Belajar dari Rumah melalui pembelajaran jarak jauh daring dan/atau luring 
dilaksanakan sesuai dengan pedoman penyelenggaraan Belajar dari Rumah sebagaimana tercantum dalam Lampiran Surat Edaran.

2. Prinsip Pelaksanaan Belajar dari Rumah

- Keselamatan dan kesehatan lahir batin peserta didik, pendidik, kepala satuan pendidikan dan seluruh warga satuan pendidikan menjadi pertimbangan utama dalam pelaksanaan BDR.

- Kegiatan BDR dilaksanakan untuk memberikan pengalaman belajar yang bermakna bagi peserta didik, tanpa terbebani tuntutan menuntaskan seluruh capaian kurikulum.

- BDR dapat difokuskan pada pendidikan kecakapan hidup, antara lain mengenai pandemi COVID-19

- Materi pembelajaran bersifat inklusif sesuai dengan usia dan jenjang pendidikan, konteks budaya, karakter dan jenis kekhususan peserta didik.

- Aktivitas dan penugasan selama BDR dapat bervariasi antar daerah, satuan pendidikan dan Peserta Didik sesuai minat dan kondisi masing-masing, termasuk mempertimbangkan kesenjangan akses terhadap fasilitas BDR.

- Hasil belajar peserta didik selama BDR diberi umpan balik yang bersifat kualitatif dan berguna dari guru tanpa diharuskan memberi skor/nilai kuantitatif.

- Mengedepankan pola interaksi dan komunikasi yang positif antara guru dengan orang tua/wali.

3. Pelaksanaan Belajar Dari Rumah oleh Guru.

Menyiapkan rencana pelaksanaan pembelajaran jarak jauh, dimana guru harus memastikan beberapa hal berikut:

- memastikan kompetensi pembelajaran yang ingin dicapai, tidak memaksakan penuntasan kurikulum dan fokus pada pendidikan kecakapan hidup;

- menyiapkan materi pembelajaran dengan fokus materi pada

a. literasi dan numerasi;

b. pencegahan dan penanganan pandemi COVID-19;

c. Perilaku Hidup Bersih dan Sehat (PHBS) dan Gerakan Masyarakat Sehat (Germas);

d. kegiatan rekreasional dan aktivitas fisik;

e. spiritual keagamaan; dan/atau

f. penguatan karakter dan budaya

menentukan metode dan interaksi yang dipakai dalam penyampaian pembelajaran melalui daring, luring, atau kombinasi keduanya;

menentukan jenis media pembelajaran, seperti format teks, audio/video simulasi, multimedia, alat peraga, dan sebagainya yang sesuai dengan metode pembelajaran yang digunakan;

- guru perlu meningkatkan kapasitas dengan mengikuti pelatihan daring yang disediakan oleh pemerintah maupun lembaga nonpemerintah guna mendukung keterampilannya.

Fasilitasi pembelajaran jarak jauh daring:

- Tatap muka Virtual melalui video conference, teleconference, dan/atau diskusi dalam group di media sosial atau aplikasi pesan

- Learning Management System (LMS). LMS merupakan sistem pengelolaan pembelajaran terintegrasi secara daring melalui aplikasi Contoh LMS antara lain kelas maya rumah belajar, google classroom, ruang guru, zenius, edmodo, moodle, siajar LMS seamolec, dan lain sebagainya

Tujuan:

- Memastikan pemenuhan hak peserta didik untuk mendapatkan layanan pendidikan selama darurat COVID-19.

- Melindungi warga satuan pendidikan dari dampak buruk COVID-19.

- Mencegah penyebaran dan penularan COVID-19 di satuan pendidikan. 
- Memastikan pemenuhan dukungan psikososial bagi pendidik, peserta didik dan orang tua/wali.

4. TIGA TUGAS UTAMA dalam mendesain dan mengimplementasikan pembelajaran jarak jauh:

a. APA:

- Materi yang harus diajarkan

- Koordinasi dengan Kepala Sekolah

$>$ Selaraskan dengan Kepala Sekolah tentang

$>$ materi/konten yang paling tepat untuk diajarkan

> Pastikan guru tetap mengikuti perubahan kurikulum, kebijakan, atau panduan yang ada.

- Yang Diperhatikan Guru

$>$ Mengikuti arahan atau panduan resmi yang diberikan Kepala Sekolah tentang apa yang harus diajarkan dan bagaimana cara mendapatkannya.

> Selalu memberikan laporan perkembangan pembelajaran, kendala selama proses pembelajaran untuk mendapatkan umpan balik dari Kepala Sekolah. Mengikuti pertemuan atau diskusi kelompok dengan Kepala Sekolah menggunakan saluran formal dan informal.

$>$ Melakukan komunikasi dengan sesama guru untuk berbagi pengalaman dan mencari solusi atas kendala yang dihadapi.

> Memastikan persetujuan dari kepala Kepala Sekolah tentang kurikulum dan rencana pembelajaran yang akan diberikan selama proses pembelajaran jarak jauh

- Review Kurikulum

$>$ Mengikuti arahan pemerintah, dan sumber daya yang dimiliki guru dan siswa. Menentukan prioritas pembelajaran:

Selengkap mungkin sebagaimana kurikulum standar,

$>$ memberikan pengalaman belajar tanpa terbebani tuntutan menuntaskan seluruh capaian kurikulum,

$>$ mencakup pengetahuan dan keterampilan inti, atau

$>$ fokus pada konten dan kegiatan yang akan membantu siswa mengatasi krisis saat ini.

- Yang Diperhatikan Guru

> Menentukan target kurikulum yang akan dicapai yang mencakup pengetahuan dan keterampilan inti, dengan lebih memfokuskan pada kesejahteraan (well-being) para siswa.

> Memastikan ada arahan atau panduan resmi yang harus diikuti untuk menerapkan rencana pembelajaran tersebut, dan sumber daya yang akan digunakan, serta rekomendasi narasumber yang harus dihubungi jika diperlukan bantuan teknis.

> Memulai pembelajaran sesuai dengan rencana pembelajaran yang telah disiapkan dan disetujui Kepala Sekolah dengan tetap mengikuti perkembangan kebijakan

b. Siapa berikutnya.

- Profil Pembelajaran

> Guru memiliki pemahaman yang mendalam tentang siswa dan bagaimana mereka belajar, hal ini akan sangat membantu Guru untuk merancang pengalaman belajar jarak jauh yang lebih baik.

$>$ Tinjau apa yang guru ketahui tentang siswa tentang pengetahuan, keterampilan, kebiasaan, dan minat mereka, kekuatan mereka dan tantangan mereka.

- Yang Diperhatikan Guru

$>$ Mengetahui siswa mana yang dapat menyelesaikan tugas sekolah mereka dengan baik sebelum sekolah ditutup dan mana yang masih belum bisa.

> Menentukan strategi pengajaran dan kegiatan belajar yang terbaik untuk siswa, diferensiasi atau strategi personalisasi yang paling efektif. 
Mengetahui siswa mana saja saya yang dapat bekerja secara mandiri dan siapa yang akan membutuhkan lebih banyak bimbingan dan dukungan belajar dari jarak jauh.

$>$ Mengetahui siswa mana saja yang merasa nyaman menggunakan teknologi dan siapa saja yang akan membutuhkan lebih banyak bantuan.

$>$ Mengetahui siswa mana saja yang dapat membantu teman sekelas dengan kegiatan belajar menggunakan teknologi.

- Status dan Kebutuhan saat ini

> Mengetahui lingkungan rumah dan kondisi psikososial siswa akan membantu guru untuk menetapkan tujuan yang realistis untuk belajar mereka

- Yang diperhatikan Guru

> Lokasi dan lingkungan rumah tinggal siswa, ditinjau dari aspek kenyamanan, keamanan, ketersediaan kebutuhan dasar yang memadai.

> Mengetahui kondisi mental dan emosi siswa, apakah cemas atau takut, apakah mereka memiliki jaringan dukungan yang kuat di dalam rumah atau di komunitasnya.

> Mengetahui kepemilikan akses ke teknologi untuk pembelajaran jarak jauh, jenisnya, seberapa sering, untuk berapa lama, dan berapa biayanya, bagaimana mereka akan mengakses materi pembelajaran, bagaimana komunikasi satu sama lain, dan siapa yang akan paling membutuhkan bantuan dalam hal akses.

$>$ Mengetahui orang tua siswa atau orang lain dalam rumah siswa yang dapat membantu dalam menyelesaikan tugas sekolah, siswa mana yang akan membutuhkan lebih banyak bimbingan dan dukungan dari guru

- Dukungan Keluarga.

$>$ Orang tua atau wali murid pasti akan memainkan peran besar dalam membantu siswa berhasil dalam pembelajaran jarak jauh.

$>$ Perlu diingat, bagaimanapun, bahwa orangtua bukan guru terlatih dan diminta untuk mengambil tugas yang menantang, sementara mereka juga berurusan dengan tugas dan tuntutan lain di rumah. Mereka akan membutuhkan banyak bimbingan dan dorongan dari guru.

- Yang diperhatikan guru

$>$ Mengetahui permintaan bantuan apa saja dari orang tua atau wali murid, kemampuan mereka, cara memastikan bahwa tugas yang diberikan kepada mereka berada dalam kemampuan mereka.

> Memastikan bahwa hasil yang diharapkan, panduan belajar, dapat disampaikan dengan jelas dari awal kepada orang tua atau wali murid dan sumber daya dan alat apa yang harus disediakan.

$>$ Menggunakan pola komunikasi dan memberikan umpan balik yang baik kepada orangtua dengan menyepakati waktu untuk berkomunikasi.

- Memberikan dukungan, dorongan, dan motivasi kepada orangtua atau walimurid untuk tetap termotivasi.

$>$ Lakukan pengumpulan informasi terlebih dahulu mengenai kesiapan orangtua dalam mendampingi murid melakukan pembelajaran jarak jauh. Faktor yang setidaknya perlu dipertimbangkan: akses orangtua terhadap teknologi, pola kerja orangtua dan tingkat pendidikan orangtua.

> Sediakan waktu berbincang bebas dengan orangtua dan murid untuk mendapatkan gambaran kondisi yang mereka alami. Membangun kepercayaan diri murid dan orangtua, menghadirkan dukungan, pendorong semangat dan bantuan professional.

$>$ Memperkirakan durasi pengerjaan tugas yang akan diberikan. Pastikan durasinya maksimal $80 \%$ dari jam belajar normal untuk menyediakan waktu belajar tidak terstruktur. Durasi ini bisa disesuaikan melalui koordinasi dengan guru yang mengajar pada kelas yang sama dan dengan siswa/orangtua

- Membangun kesepakatan dengan orangtua terkait cara pengerjaan tugas murid, jadwal dan durasi konferensi guru 
c. Bagaimana Desain dan Implementasi Pembelajaran Jarak Jauh

- Penilaian Diri Guru

$>$ Berganti dari pembelajaran tatap muka ke pembelajaran jarak jauh di tengah krisis yang belum pernah terjadi sebelumnya, dengan sedikit pengalaman atau persiapan, akan menjadi tantangan besar bagi para guru. Sekarang, guru perlu menjadi kreatif dan fleksibel dengan tetap teguh pada prinsip pengajaran yang baik dan pembelajaran inklusif.

$>$ Bangun kekuatan pribadi dan profesion al, akui tantangan dan mengatasinya, serta ulurkan tangan kepada sesama guru dan Kepala Sekolah untuk bantuan dan bimbingan.

- Yang diperhatikan Guru

> Menyadari peran sebagai guru telah berubah sebagai akibat dari penutupan sekolah dan menyadari kesiapan untuk mengambil peran yang berubah ini secara fisik, intelektual, mental dan emosional.

> Menyikapi segala kekhawatiran atau ketakutan untuk mengajar jarak jauh dan menyiapkan diri dengan lebih baik agar merasa lebih mampu untuk mengambil tantangan ini.

$>$ Menyiapkan sarana teknologi dan sumber daya yang tersedia yang dapat digunakan secara nyaman, dan mendapatkan akses lebih banyak terhadap teknologi yang dibutuhkan.

$>$ Menyadari kemampuan diri terhadap teknologi, mengikuti pelatihan ekstra untuk pengajaran jarak jauh jika diperlukan sesuai dengan kebutuhan pribadi.

$>$ Menyiapkan dan membuat alat dan sumber daya sesuai dengan waktu yang tersedia dan target kurikulum yang telah ditetapkan.

- Dukungan Guru

$>$ Mengajar jarak jauh tidak mudah dan juga tidak disukai, dan tidak perlu dilakukan sendiri. Temukan dukungan yang diperlukan:

$>$ Dukungan profesional

$>$ Dukungan Emotional

$>$ Dukungan teknis

- Yang diperhatikan guru

$>$ Memastikan jenis dukungan apa yang diperlukan.

$>$ Mencari informasi saluran resmi untuk dukungan guru seperti hotlines, helpdesk, atau group online.

$>$ Melakukan komunikasi dengan kelompok guru di sekolah sendiri atau kelompok guru sejenis terkait dengan dukungan teknologi atau motivasi yang diperlukan.

$>$ Memastikan guru sudah memiliki kelompok yang akan memberikan dukungan baik dari sekolah sendiri maupun dengan guru dari sekolah lain.

> Memastikan dan mencari model pembelajaran jarak jauh yang sudah berhasil dilaksanakan secara efektif selama masa pandemi corona ini yang dapat dicontoh.

- Sumber Daya

$>$ Ketika guru membuat pergeseran dari tatap muka ke pembelajaran jarak jauh, pikirkan tentang bagaimana guru perlu menyesuaikan strategi dan materi. Salah satu faktor penting untuk dipertimbangkan adalah sumber daya apa yang tersedia untuk guru dan siswa Anda.

- Yang diperhatikan Guru

> Memastikan teknologi, platform, peralatan dan sumber daya yang tersedia bagi guru dan siswa - cetak, audio dan radio, video dan TV, berbasis komputer, berbasis Internet dan berbasis telepon.

$>$ Manakah dari sumber daya ini yang dapat digunakan oleh semua atau sebagian besar siswa dan manakah yang termudah untuk digunakan untuk komunikasi, instruksi langsung, diskusi, berbagi pekerjaan dan penilaian?

$>$ Manakah dari siswa yang tidak memiliki akses ke telepon, komputer, internet? 
$>$ Memastikan materi pengajaran dan pembelajaran yang dapat diadaptasikan untuk pembelajaran jarak jauh. Mencari sumber daya pendidikan yang dapat bebas diakses dan memastikan sumberdaya tersebut berkualitas.

- Menyusun Pembelajaran

$>$ Guru menyusun struktur pembelajaran jarak jauh bergantung pada apa yang diajarkan, siapa yang diajar, kemampuan pribadi dan sumber daya yang tersedia. Ingatlah refleksi mengenai hal ini saat akan mendesain pengalaman belajar jarak jauh.

> Skenario A: lengkap, pelajaran terstruktur mengikuti kurikulum standar

$>$ Skenario B: lengkap, pelajaran terstruktur difokuskan pada pengetahuan dan keterampilan inti

$>$ Skenario C: konten pembelajaran dan kegiatan yang dipilih untuk membantu siswa mengatasi krisis saat ini

- Dukungan dan Umpan Balik kepada Siswa

Sebelum:

mengklarifikasi tugas dan mengelola hasil yang akan diharapkan

Selama:

$>$ memantau kemajuan dan pembelajaran melalui refleksi secara berkala

$>$ memberikan umpan balik dan dukungan secara terus menerus

Setelah:

mengelola penilaian sumatif dan memberikan umpan balik dari proses

pembelajaran

- Penilaian

$>$ Penilaian harus direncanakan dan dilekatkan dalam kegiatan belajar. Hal ini akan memungkinkan guru untuk memonitor dan memfasilitasi kemajuan belajar siswa, dan membantu siswa mengelola pembelajaran mereka sendiri.

$>$ Perlu dipikirkan juga bagaimana guru akan menilai hasil pembelajaran.

$>$ Pada akhirnya, metode penilaian yang digunakan akan tergantung pada tujuan belajar ditetapkan.

$>$ Temukan keseimbangan antara apa yang efektif dan apa yang layak untuk dilakukan dari jarak jauh.

Pelaksanaan kegiatan pengabdian kepada guru-guru sekolah di bawah naungan KN-LWF Pematangsiantar dimaksudkan untuk membantu sosialisasi kepada guru-guru terkait Pembelajaran daring pada masa Pandemi Covid 19 tujuannya mencegah kesalahan penggunaan pembelajaran online yang keliru. Cara efektif untuk mencegah hal tersebut adalah pengambilan tindakan yang tepat terhadap guru-guru, agar mereka memiliki konsep pembelajaran Online yang efektif dan efesien sehingga diharapkan mampu memberikan wawasan tentang pentingnya pemilihan media, strategi, dan aplikasi pendukung pembelajaran online.

Tahapan kegiatan yang dijalankan meliputi persiapan, pelaksanaan, monitoring dan evaluasi, pembuatan laporan, dan penyerahan laporan akhir. Penyuluhan ini dilakukan dengan target utama adalah guru-guru yang dapat membantu mendistribusikan pengetahuannya ke peserta didik. Oleh karena itu untuk memecahkan permasalahan di atas, maka dilakukan hal-hal sebagai berikut:

1) Melakukan koordinator teknis di lapangan dengan Kepala Sekolah, untuk mempersiapkan kegiatan yang akan dilaksanakan.

2) Sekolah target diharapkan mengirimkan utusan peserta penyuluhan.

3) Penyuluhan dilaksanakan di kantor guru dan diikuti oleh peserta rata-rata 5 sampai dengan 10 orang yang merupakan perwakilan dari tiap mata pelajaran dan kelas.

4) Materi penyuluhan disusun oleh Tim Pelaksana Pengabdian Kepada Masyarakat USI yang terdiri dari staf pengajar di FKIP USI.

5) Materi penyuluhan disusun dalam bentuk makalah dan diperbanyak sesuai dengan jumlah peserta penyuluhan. 
6) Selain materi dalam bentuk makalah, untuk keperluan peragaan, demonstrasi dan praktik, Tim pelaksana juga menyediakan alat-alat dan bahan-bahan yang diperlukan untuk kegiatan penyuluhan tersebut.

Di akhir kegiatan ini dilakukan evaluasi dan diberikan angket untuk mengetahui tentang tanggapan dari setiap peserta terhadap pelaksana pengabdian kepada masyarakat yang dilakukan oleh Tim Pelaksana Pengabdian dari Universitas Simalungun

\section{HASIL DAN PEMBAHASAN}

Kegiatan pengabdian kepada masyarakat dilakukan oleh tim dari PKM Universitas Simalungun pada tanggal 31 Maret 2021. Sosialisasi bertujuan agar guru-guru paham bagaimana pembelajaran 4.0, Penggunaan Strategi, Media, dan Aplikasi yang tepat, serta proses pembelajaran online yang efisien. Program ini pada akhirnya diharapkan dapat mensukseskan program pemerintah dan memberi dukungan bagi guru-guru melakukan proses belajar. Tujuan Belajar dari Rumah Melalui Pembelajaran Jarak Jauh 1. Memberikan pengalaman belajar yang bermakna bagi siswa, tanpa terbebani tuntutan menuntaskan seluruh capaian kurikulum kenaikan kelas maupun kelulusan. 2. Memfokuskan pada pendidikan kecakapan hidup antara lain mengenai pandemi Covid-19. 3. Memberikan variasi aktivitas dan tugas pembelajaran belajar dari rumah antarsiswa, sesuai minat dan kondisi masing-masing, termasuk mempertimbangkan kesenjangan akses/fasilitas belajar dari rumah. 4. Memberikan umpan balik terhadap bukti atau produk aktivitas belajar dari rumah yang bersifat kualitatif dan berguna bagi guru, tanpa diharuskan memberi skor/nilai kualitatif mengajar selama era pandemi.

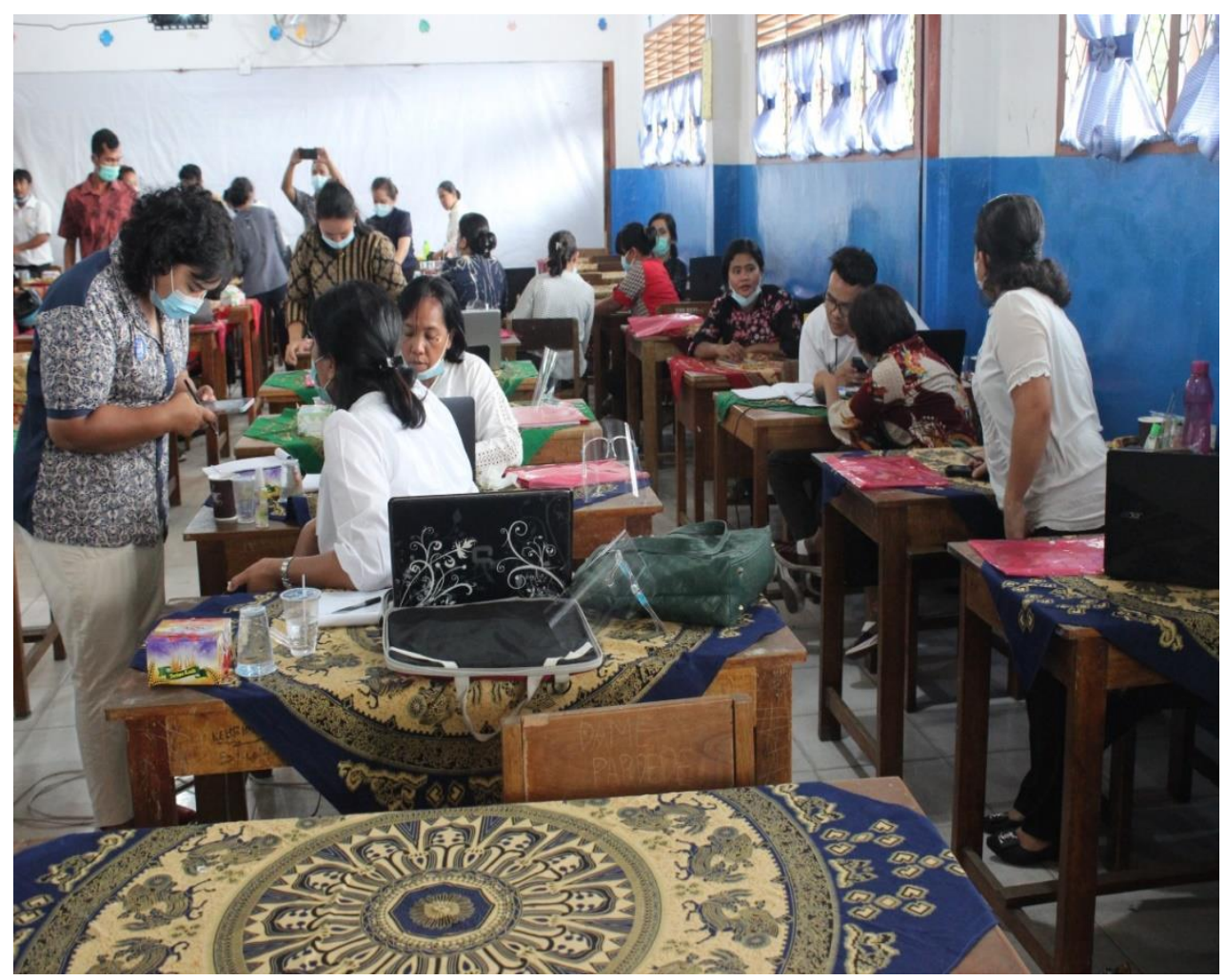

Gambar 1. Para pendidik secara Aktif dan Antusia memperatekkan Pelatihan pembelajaran Online 


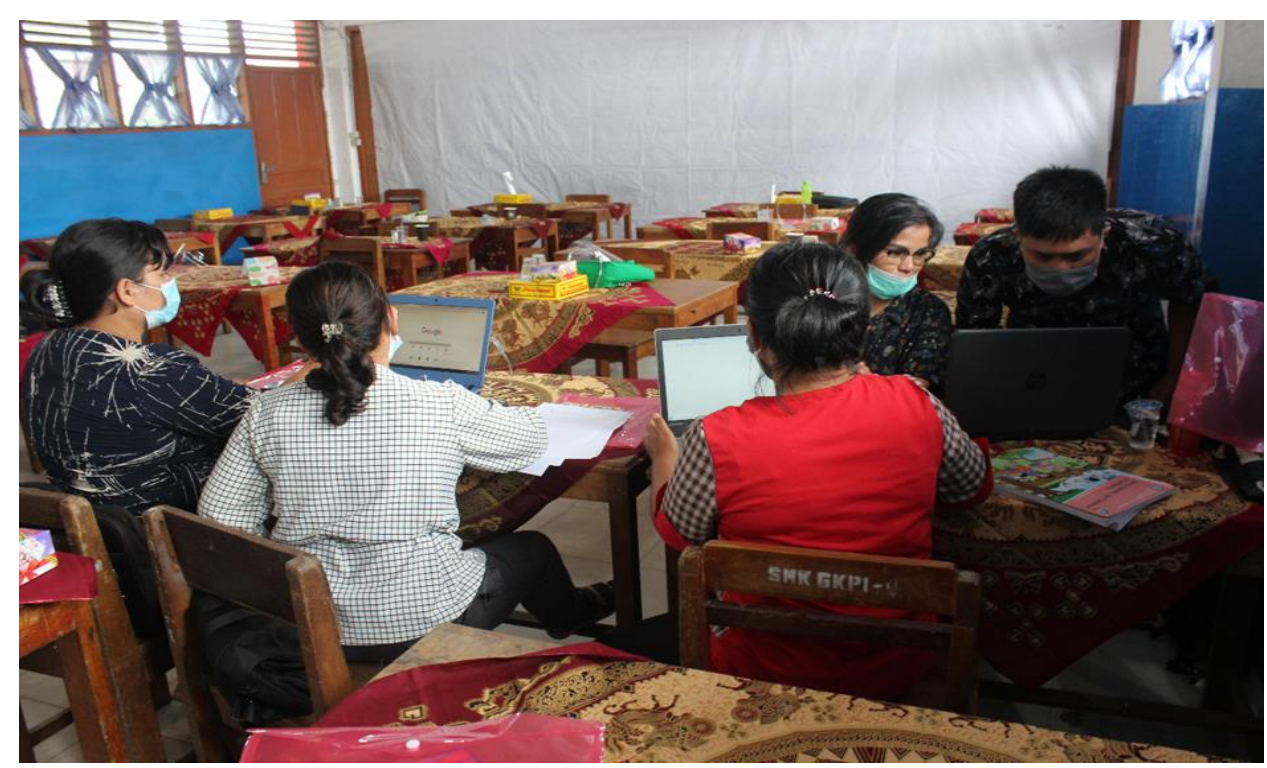

Gambar 2. Para pengajar secara serius Mengaplikasikan pelatihannya dengan bimbingan Dosen

\section{SIMPULAN}

Berdasarkan kegiatan yang telah dilakakukan terdapat beberapa temuan yaitu faktor pendukung kegiatan tersebut antara lain dimana Para peserta sosialisasi memiliki kemauan yang besar untuk mendapatkan informasi dan pengetahuan mengenai Pembelajaran Online masa Pandemi Covid 19. Serta cara penggunaan Strategi, Media, Aplikasi pendukung pembelajaran yang tepat. Kegiatan sosialisasi Pembelajaran online masa pandemi covid 19 sangat didukung oleh aparat setempat baik secara langsung maupun tidak langsung berpartisipasi secara aktif dalam pelaksanaan pelatihan tersebut melalui protokol kesehatan yang ketat. Pihak pemerintah daerah setempat menyediakan fasilitas tempat kegiatan yang cukup representative untuk melaksanakan sosialisasi terebut serta dukungan untuk mengikuti kegiatan sosialisasi dengan seksama.

Beberapa kendala yang dihadapi pada saat dilapangan. Adanya keterbatasan dalam fasilitas pendukung untuk melakukan sosialisasi dan presentasi, diantaranya tidak adanya LCD proyektor. Dimana Kegiatan pelatihan yang direncanakan berjalan 2 hari tidak dapat terealisasi dikarenakan terbentur dengan jadwal mengajar guru dan yang berkerja dari rumah (work from home). Sehingga tim sosialisasi agak repot untuk menyesuaikan waktu yang cocok. Sosialisasi pembelajaran online masa pandemi covid 19 merupakan kegiatan yang memiliki kontribusi yang besar bagi Sekolah untuk meningkatkan kesadaran guru-guru akan pentingnya pemhaman yang mendalam terkait pembelajaran masa pandemi covid 19 dan pemilihan strategi, media, serta aplikasi yang mendukung guru dalam kesuksesan proses pembelajaran online di masa pandemi.

\section{SARAN}

Pimpinan KN-LWF Pematangsiantar diharapkan lebih gencar dalam memantau proses KBM yang dilaksanakan guru-guru sekolah di bawah naungannya, serta melakukan sosialisasi tentang Pembelajaran daring yang efektif dan efisien dalam masa pandemi covid 19 ini

Perlu dilakukan kerjasama dengan Perguruan Tinggi, Pemerintah Daerah, dan Instansi pendidikan agar dapat melaksanakan pembelajaran daring yang efektif dan efisien serta menghasilkan guru-guru yang kreatif dan inovatif dalam proses pembelajaran daring selama masa pandemi covid-19. 


\section{UCAPAN TERIMA KASIH}

Pada kesempatan ini, tidak lupa peneliti ucapkan terima kasih yang sebesar-besarnya kepada semua pihak yang telah membantu sehingga pengabdian ini dapat terlaksana dengan baik, terutama kepada :

1. Rektor Universitas Simalungun

2. Ketua Lembaga Pengabdian Pada Masyarakat (LPM) USI

3. Dekan FKIP Universitas SIMALUNGUN

4. Pimpinan KN-LWF Pematangsiantar

5. Rekan-rekan Dosen Tim PKM

6. Pihak-pihak lain yang tidak dapat penulis sebutkan satu persatu

Semoga segala bantuan dan kebaikannya mendapat balasan yang setimpal dari Tuhan YME.

\section{DAFTAR PUSTAKA}

Anugrahana, A. (2020). Hambatan, Solusi dan Harapan: Pembelajaran Daring Selama Masa Pandemi Covid-19 Oleh Guru Sekolah Dasar. Scholaria: Jurnal Pendidikan dan Kebudayaan, 10(3), 282289. https://doi.org/10.24246/j.js.2020.v10.i3.p282-289

Asmuni.(2020). Problematika Pembelajaran Daring di Masa Pandemi Covid-19 dan Solusi Pemecahannya. Jurna Pedagogy. Diunduh dari: https://ejournal.undikma.ac.id/index.php/pedagogy/article/view/2941

Anugrahana, A. (2020). Hambatan, Solusi dan Harapan: Pembelajaran Daring Selama Masa Pandemi Covid-19 Oleh Guru Sekolah Dasar. Scholaria: Jurnal Pendidikan dan Kebudayaan, 10(3), 282289. https://doi.org/10.24246/j.js.2020.v10.i3.p282-289

Dewi, W. A. F. (2020). Dampak Covid-19 terhadap implementasi pembelajaran daring di Sekolah Dasar. Edukatif: Jurnal Ilmu Pendidikan, 2(1), 55-61.

Fahrina, A., Amelia, K., \& Zahara, C. rita. (2020). Minda Guru Indonesia: Peran Guru Dan Keberlangsungan Pembelajaran di Masa Pandemi Covid-19. syiah Kuala University Press.

Hilna Putria, dkk (2020). Analisis Proses Pembelajaran dalam Jaringan (DARING) Masa Pandemi Covid- 19 Pada Guru Sekolah Dasar. Jurnal Basicedu. Diunduh dari: http://jbasic.org/index.php/basicedu/user/register

Kemendikbud. (2020). Buku Saku Panduan Pembelajaran di Masa Pandemi Covid-19

Pendidikan, M. (n.d.). Surat Edaran Nomor 3 Tahun 2020 Tentang Pelaksanaan Pendidikan dalam Masa Darurat CoronaVirus (COVID-19). 2020.

Sanjaya, Ridwan . (2020). 21 Refleksi Pembelajaran Daring di Masa Darurat. Semarang : Universitas Katolik Soegijapranata 